\title{
Mülkiyet, Adalet ve Devlet: Metin Erksan'ın Üçlemesi Ekseninde Bir Tartışma
}

\author{
Belgin Tarhan* \& Bora Tarhan**
}

\section{Öz}

1960’lı yıllarda yönetmen Metin Erksan, odağında mülkiyet meselesi olan üç film çeker. Her bir filmde, mülkiyet ilişkilerinin farklı bir unsuruna yönelir. Yılanların Öcü ortak olanın idaresini, Susuz Yaz özel mülkiyeti haklı gösteren sahipliğin kaynağını, Kuyu ise insanın mülkiyet konusu olmasını sorunsal haline getirir. Üç filmde de mülkiyet kökenli sorun ve çatışma, toplumsal olarak birlikte yaşama pratiği ve idealine zarar verecek adalet problemine dönüşmektedir.

Bu çalışmada Erksan'ın Üçleme'sinde yer alan temalar, siyaset felsefesinin alanına çekilmektedir. Sahiplik ve paylaşım kavramları etrafında mülkiyet ilişkilerinin doğasına ilişkin bir sorgulama yapılmaktadır. Adalet sorunuyla birlikte hukuk ve devlet kavramları da tartışmaya dâhil edilmektedir. Son kısımda ise hukuk ve yasanın üstesinden gelmediği sorunlarla baş başa kalan insanların direniş biçimleri yorumlanmaktadır.

Anahtar Kelimeler: Özel Mülkiyet, Ortak Mülkiyet, Adalet, Devlet, Direniş, Susuz Yaz, Yılanların Öcü, Kuyu.

\section{A Discussion Based on Metin Erksan's Trilogy: Property, Justice and State}

\section{Abstract}

In the 1960s, the director Metin Erksan produced three films that put the issue of property to the center. In each film, he deals with a different component of property relations. Yılanların Öсӥ explains the management of the common, Susuz Yaz questions the source of ownership justifying private property and Kuyu treats man as the subject of ownership. The conflict over property ultimately metamorphosed into the problem of justice that would harm the practice and ideal of social coexistence.

In this study, the themes in Erksan's trilogy will be involved in the field of political philosophy. The nature of property relations around the concepts of ownership and sharing will be discussed. The concepts of law and state together with the question of justice will also be included in the discussion. In the last part, the resistance of people who are alone with the problems that are not overcome by law and legislation will be interpreted.

Keywords: Private Property, Coownership, Justice, State, Resistance, Susuz Yaz, Yılanların Öcü, Kuyu.

\footnotetext{
‘Dr., Öğr. Üyesi | Adnan Menderes Üniversitesi Söke İşletme Fakültesi

belgin.buyukbuga@adu.edu.tr | ORCID: 0000-0002-0950-3363 | DOI: 10.36484/liberal.844989

"Dr., Öğr. Üyesi | Adnan Menderes Üniversitesi Söke İşletme Fakültesi

bora.tarhan@adu.edu.tr | ORCID: 0000-0002-5710-3241 | DOI: 10.36484/liberal.844989

Liberal Düşünce Dergisi, Yıl: 26, Sayı: 101, Kış 2021, ss. 7-26.

Gönderim Tarihi: 22 Aralık 2020 | Kabul Tarihi: 9 Mart 2021
} 


\section{Giriş̧}

1960’lı yıllarda yönetmen Metin Erksan, insanlığın en temel çatışmalarından biri olan mülkiyet meselesine ilişkin filmler çeker: Yılanların Öcü (1962), Susuz Yaz (1963) ve Киyu (1968). Her birinde insanlığın temel meselelerini 'sahiplik' eksenindeki sorularla derinleştirir. Toplumsallık içindeki insanın sahiplik algısı ile mülkiyet kavrayışını felsefi bir düzlemde yorumlar. İlk bakışta yerelliği ağır basan öyküler, Erksan'ın sinema dilinde ucu insanlığın ezeli ve ebedi çatışmalarına varan evrensel temalara dönüşür. Kült haline gelen diğer eserlerinin yanı sıra bu metnin konusu olan üç film de farklı yönleriyle mülkiyet ilişkilerinden çıkarak hak ve adalet sorununu ele alır.

Susuz Yaz özel mülkiyet, Yılanların Öcü ortak mülkiyet üzerindeki anlaşmazlığı konu edinir. Diğer ikisinden ayrıksı olmakla birlikte daha çarpıcı şekilde üçlemeye bağlanan Kuyu ise, bugün ussal ve yasal olarak kabullenemeyeceğimiz, lakin pratikte devam eden insanın insan üzerindeki sahipliğini ele alır. Susuz Yaz, Necati Cumalı'nın 1962 yılında yayımlanan öykü kitabında yer alan bir hikâyedir. Yılanların Öcü, Fakir Baykurt'un 1958 yılında aynı adı taşıyan köy romanın senaryolaşmasının ürünüdür. Kuyu ise, diğer ikisi gibi edebi bir esere dayanmaz. Kuyu'nun senaryosu, 1968 yılında gazetenin üçüncü sayfasında yer alan 5-6 satırdan ibaret bir haberden yola çıkan Metin Erksan tarafından oluşturulur. İlk bakışta sıradan bir cinayet olayı gibi görünen haber kupürü, Erksan'ın zihninde taşıdığı mülkiyet meselesinin bir başka boyutunu gösteren senaryoya dönüşür.

Metin Erksan'ın gençlik yıllarında tanıştığı sosyalist fikirlerin sanat hayatına, eserlerine etkisinin yüksek olduğu fark edilebilir. Fikri ideolojik zihin dünyası ekseninde insanlığın çözümleme kavuşturamadığı evrensel temaların memleketinin insanlarının da yaşadığı sorunlar olarak sinemaya taşımıştır. İster sosyalist ister liberal perspektiften olsun Erksan'ın üçlemesi, toprak, su ya da kadın/insan üzerine kurulan sahipliğin neden olduğu adaletsizlik, bir arada yaşama pratiğini sakatladığı için sorunu gözler önüne sermeye ve tartışmaya muhtaçtır. Erksan (2014) verdiği bir röportajda yıllarca zihninde mülkiyet meselesiyle dolaştırdığını söyler. Daha geniş bir aralıktan bakıldığında yönetmenin Acı Hayat (1962) ve Sevmek Zamanı (1965) gibi filmlerinde de sahipliğin kaynağı ve anlamını aradığı fark edilebilir. Evlenme niyetinde olan yoksul çiftin gündelik/aylık kazançlarıyla ödeyecekleri kiralık bir ev bulamamaları, Acı Hayat'ın konusunu oluşturur. İki kişinin gelirinin iki göz odadan ibaret bir gayrimenkulü karşılayamaması, özünde mülksüzlerin büyük şehirde benliklerinden taviz vermeksizin yaşayamayacaklarının bir ifadesidir. Sevmek Zamaninda ise sahipliğin maddi olmayan biçimi ele alınır. 
Ekseriyetle Doğu'lu imgelerle ve sufi niteliğiyle anılan filmde, aşk hissinin sahibinin kim olduğu sorulur. Düşün dünyasını sanatla imgeleyen yönetmen Erksan'ın filmlerinde sahiplik/mülkiyet sorgusu, kimi zaman bireyin iç dünyasına kimi zaman da toplumsal ve siyasal katmanlara inerek yapilmaktadır.

$\mathrm{Bu}$ çalışma, öykü ve roman gibi sinema sanatının da odaklandığı şeyin biricikliğinden yola çıkarak felsefe ve beşerî bilimlerin genel alanına taşınabilecek meseleleri çözümlemeyi denemektedir. Erksan'ın yıllarca zihninde gezdirdiği mülkiyet sorununu daha geniş bir çerçeve içinde ele almak için tartışmayı siyaset felsefesinin zeminine çekmek gerekmektedir. Mülkiyet, adalet ve siyasal düzene ilişkin bir çözümleme için Thomas Hobbes, John Locke ve Jean-Jacques Rousseau'nun kuramlarından yola çıkmak mümkündür. Bu çalışmada söz konusu kuramlarla Üçleme'nin problematiği arasında iki yönlü bağ kurulmaktadır. İlki, özellikle Locke ve Rousseau'nun düşüncesinde öne çıkan mülkiyet kavramının anlamı, çıkışı ve sonuçları üzerine tartışmaların Üçleme'deki her bir kurguda gelişerek devam ettiği tespitinden doğmaktadır. İkincisi, sözleşme kuramlarındaki doğa durumu kurgusuyla Erksan'ın kurduğu adaletsiz dünya arasındaki benzerlikten türemektedir. Yalnız Erksan'ın senaryolarında mülkiyet kaynaklı gayri adil durum, bir tür 'devletli doğa durumu' içinde geçer. Bu bakımdan Üçleme, sahiplik/mülkiyet temelli anlaşmazlıklarla birlikte adaletsizliğin ve siyasal düzenin çelişkilerini açığa çıkarmaya katkı sağlamaktadır.

Çalışmanın ilk kısmında, mülkiyet gibi bir meselenin yaratımına olanak sağlayan mekân ve zaman/dönemle bağ kurulmaktadır. Keza, yönetmen Erksan gibi öykü ve romanın sahibi olan Fakir Baykurt ile Necati Cumalı'nın kıra ait sorunları içeren kurguları önem kazanmaktadır. İkinci kısımda öykülerdeki meseleler ödünç alınarak, mülkiyet ilişkilerinin doğasına dair bir soruşturma yapılmaktadır. Aynı zamanda adalet problemi ekseninde devletin konumu tartışmaya açılmaktadır. Çalışmanın son kısmında ise neredeyse tek başlarına adaletsizlikle mücadele edenlerin farklı direnişlerine yer verilmektedir.

\section{Mekân, Zaman ve Yaratıcılar}

Erksan'ın öykü, roman ve gazete haberinden yola çıkarak oluşturduğu üç senaryoda, zaman-mekân bakımından ortaklık vardır. Üç hikâyenin/senaryonun mekânı kırsaldır yani köydür. Senaryoya dönüşen üç hikâye neredeyse insanlığın başlangıcına gidermişçesine kırsaldaki sahiplik ve paylaşım mücadelesini ele alır. Kırsal, kurgusal bir akıl yürütmeyle sahiplik ve paylaşım kavgasının hangi koşullarda ortaya çıktığına dair bir fikir yürütmeye imkân sunar. Öte yandan kırsal, 1960’lı yıllarda terk edilen ve geri bırakılmak istenen mekân 
olsa da hala zihinlerdedir. Cumalı ve Baykurt gibi köy ve kasabada yetişmiş yazarların yanında yaşamını şehirde geçirmiş olan Erksan'ın da görüş alanında kırsal vardır. Hikâye ve senaryolarda, kırsal olduğu gibi tüm gerçekliğiyle gözler önüne serilmektedir.

Üç yaratıcı da Cumhuriyetin kuruluş yıllarında doğar ve yetişirler, sanatsal üretimleri ise 1950 sonrasında başlar. Çok partili siyasal hayatın kesintiye uğradığ1 1960'lı yılların başı, başta siyasette olmak üzere kültür ve sanat camiası için de içinden geçilen zamanı ve geçmişi yeniden düşünme aralığı sunar. Geçen zaman, çok partili dönemden tek parti dönemine dek Cumhuriyet rejiminin başardıklarının yanı sıra üstesinden gelemediği meselelerin muhasebesini yapmak için elverişlidir. Cumhuriyet'in ilk yıllarından itibaren toprak düzeninde adil paylaşımı sağlamak ve aşiret bağlarını kaldırmak amacıyla Köy Kanunu (1924) ve Aşar Vergisi'nin kaldırılması (1925) gibi köylü lehine yasal düzenlemelere gidilmiştir (Dik, 2016:708-9). Ağalık düzeni ve ilişkilerini çözmeye dönük politikalar merkezi idarenin görüş alanında olsa da kararlılıkla üzerine gidilemediği için kırdaki kökleşmiş yapı varlığını ve hâkimiyetini korumayı sürdürmüş görünmektedir. Kırdaki mevcut düzen, iktidar(ların) el değiştirmesinden de etkilenmemektedir. İktidarın CHP'den DP’ye geçmesiyle kırsala yaklaşımda farklılık belirse de yönelimin nedeni ekonomik gerekçelerdir. Tarımsal üretime verilen önemle birlikte DP iktidarı, 1950'den sonra kırsalı iktisadi bir güç/depo olarak görmektedir (Takım, 2012: 168). Lakin ekonomik değerin ötesine geçmeyen bir önemle, kırsal yine merkezi idareye eklemlenemez. Nüfusun şehirlere aktığı 1960’lı yıllarda, merkezi idarenin köy ve kır politikalarının yerleşik ilişkiler karşısındaki sınırlılığının kanıksanmış hali hikâye ve senaryolara da yansımaktadır. 1960'lı yılların diğer pek çok kaleminde rastlanacağı gibi Cumalı, Baykurt ve Erksan'ın kurgularında kırsal, medeniyeti temsil eden şehirden farklı olarak ilkelliğinin yanında kendi haline bırakılmış, ihmal edilmiştir. Öyle ki, kırsalın/köyün terk edilmişliği, ancak asayiş sorununu da doğuran cinayet gibi büyük vakalarda suçlu ya da suçluları almak üzere gelen jandarma ile kendisini gösterir. Ne kır, merkezi idarenin sunduğu imkânlar ile şehrin medeni ilişkilerine taliptir, ne de diğerin kıra ulaşma yönünde kalıcı adımlar atma kararlılığındadır.

Hikâye ve senaryoların yaratıcıları, özgün kişiliklere ve yaşam öykülerine sahiptirler. Pek çok farklılıklarının yanı sıra bu çalışma özelinde belirgin hale getirilebilecek ortaklıkları yaşadıkları çağın bilgisine sahip aydınlar olarak yetiştikleri toplumu cesur bir şekilde tahlile tutabilme gücüne haiz olmalarıdır. Yılanların Öcü romanının yazarı Fakir Baykurt, köyde doğmuş ve büyümüştür. Toplumsal gerçekçi köy romanlarının yazarı Baykurt köy enstitüsünde okumuş yoksul köylü bir ailenin üyesidir (Baykurt, 1998: 32). Baykurt gibi 
köy enstitülerinde okumasa da Susuz Yaz adlı öykünün sahibi Necati Cumalı da bir köyde, Urla'da (İzmir) yetişmiştir. 1923 Nüfus Mübadelesiyle Yunanistan'ın Florina köyünden İzmir'in Urla köyüne yerleşmiş mübadil bir ailenin çocuğudur. İlköğrenimini köyde tamamlayan Cumalı, önce İstanbul'da sonra Ankara'da hukuk fakültesinde okuduktan sonra avukatlık mesleğini icra etmek üzere memleketine döner. Avukatlık yaptığı İzmir'de uzun süre Urla'dan gelen köylülerin sorunlarına ilişkin davalara bakar (Akçaoğlu, 2003: 3). Baykurt ve Cumalı eserlerinde, yaşadıkları memleketin ve onun insanlarının öykülerini anlatırlar. Metinlerindeki köy/kırsal folklorik bir öğe/fon değildir; feodal ilişkilerin hâkimiyetindeki üretimin gayri adil koşullarının gerçekçi bir bakışla yansıtıldığı mekânlardır.

Cumalı ve Baykurt'tan farklı olarak Metin Erksan, İstanbul'da yaşamıştır. Üniversitelerinde henüz sinema gibi bir sanatın eğitiminin verilmediği 1940'lı yılların Türkiye'sinde bilinçli bir tercihle sanat tarihi okumaya karar verir (Erksan, 2015). Çoğu Alman olan üniversite hocalarından antropoloji, tarih, toplum ve felsefe sahasına uzanan geniş bir birikim elde etme fırsatına sahip olur (Kayalı, 2004: 58). Hocalarının diğerleri ise Hilmi Ziya Ülken, Halide Edip Adıvar, Ahmet Hamdi Tanpınar, Ömer Lütfi Barkan gibi dönemin önde gelen entelektüelleridir (Gündoğdu, 2017: 29). Daha 1950’li ylllarda sinema üzerine yazılar yazan Erksan'ın düşünceleri, sol eğilimlerin henüz yaygın ve etkili olmadığı bir ortamda şekillenir (Kayalı, 2015: 16). Bilhassa 1960'lı yıllarda solun canlanışı, toplumsal sorunları öne çıkaran filmlere yönelik ilgiyi dünya çapında da popüler kılar. Erksan bu konjonktürün içinde bir düşün adamı gibi problematiğini sinematografik olarak yansıtmayı başarır. Sinemayı sanat tarihi ve estetik perspektifi içinde görür (Kayalı, 2004: 23). Geniş ve derin entelektüel birikimi, yaşadığı çağın ve memleketin meselelerini insanlığın ezeli ve ebedi sorunlarıyla bütünleştirmesine imkân vermektedir. ${ }^{1}$ Bu yönüyle Erksan sinema sanatı içinde uğraş veren bir yönetmen olarak anılmaktan ziyade onun rejisör kimliğini de besleyen entelektüel birikimiyle tanınmaktadır. Kayalı'nın da (2004: 13-14) sıklıkla vurguladığı gibi Erksan, önce bir entelektüeldir. Dünyayı ve içinde yaşadığı toplumu tüm gerçekliğiyle tanımaya ve anlamaya çalışan bir entelektüel olarak düşüncelerini yalnızca sinema aracılığıyla aktarma yolunu seçmez. 1965 genel seçimlerinde Türkiye İşçi Partisi listesinden İstanbul bağımsız milletvekili

1 Sinema filmlerinin yanı sıra içinde sinemanın da olduğu toplumsal ve siyasal meseleleri içeren kitaplar kaleme alır. Erksan'ın gün yüzüne çıkmamış yazılarının dışında yayınlanan eserleri şunlardır: Atatürk Filmi, Hil Yayınları, 2000; Mare Nostrum, Bizim Deniz Yunan Sorunu, Hil Yayıncılık, 1997; Türkiye Cumhuriyeti Devleti’nin Avrupa Topluluğu Üyesi Olmak Hakkı ve İsteğinin Tarihsel Kaynakları, Hil Yayıncılık, 1991. Erksan'ın yayınlanmış bir de söyleşi kitabı vardır: Aşktan, Ölümden Başka Bir Şey Kalmadı, Haz. Enes Batur, Kırmızı Kedi Yayınevi, 2017. 
adayı olması düşünsel birikimin söze ve eyleme dökülmesi çabasının sonucu olarak görülebilir.

\section{Mülkiyet Kavrayışına İlişsin Üç Soruşturma}

\section{Özel Mülkiyetin Kaynağı Üzerine}

Susuz Yaz, yazarı Necati Cumalı'nın avukatlık dönemindeki tanıklıklarına dayanır. Öykü Erksan'ın elinde ise mülkiyet sorununu merkeze alan bir senaryoya dönüşür (Kayalı, 2015: 23). Cumalı da hikâyede paylaşım, mülkiyet, adalet ve hukuk gibi unsurlara dikkat çekmektedir lakin görsel olarak sahip olunan avantajlar, başka bir ustanın elinde sinemayı edebiyattan daha geniş kesimlerle buluşturmaya elverişli hale getirmektedir.

Susuz Yaz, ele aldığı diğer temaların² yanında, sahipliğin başlangıcını irdeler. Yazları kurak geçen bir köyde, nadir olan su kaynağının sahipliğinin kimde olduğunu sorar. Köylülerden birinin toprakları dâhilinde çıkan suyu, diğerleri ile paylaşmaya yanaşmaması sonucu çıkan anlaşmazlığın ürettiği toplumsal huzursuzluk, adaletsizlik ve asayiş problemini konu edinir. Herkesin birbirini tanıdığı ve/veya akrabalık bağlarının bulunduğu köyde hâkim olan kardeşlik ve barış̧̧ıl düzen yerini düşmanlığa ve çatışmaya bırakır. Bencillik veya paylaşım gibi iki tercihten birine peşinen onay vermek yerine öncelikle sorunun en başına yani sahipliğin niçin ortaya çıktığı, nasıl gerekçelendirildiği sorulmalıdır. Zira öykü hâlihazırda toprak ya da hava gibi paylaşılmış ya da paylaşım ilkelerine dâhil olmuş bir şeyi değil, toprağın altında gezinen su gibi mülkiyet ve/veya paylaşıma dâhil olmamış yepyeni bir konuyu tartışmaya açmaktadır.

Özel mülkiyet rejimi, herkese ait olandan çalınarak edinildiği iddiası ile kolektif anarşist düşünce ile komünizm taraftarı geniş bir sol kesim tarafından gayri adil görülmektedir. Keza ilk sahiplik, mübadele gibi barışçıl yollarla gerçekleşe bile sonrasında cebre dayalı zorlamalarla korunduğu ve genişletildiği için mülkiyet ilişkilerinin (en azından başlangıçta) gayri adil yollarla devam ettiği ileri sürülebilir. Dolayısıyla iki şekilde de mülkiyet gayri adil yollarla elde edilmiş ve biriktirilmiş olmaktadır. Oysa başlangıçta tabiatın zengin, buna karşın insan nüfusunun son derece az olduğu mant1ken kabul edilebilir bir savdır. Mülkiyet teorisyenlerinden John Locke (2004:

21963 yılında çekilen Susuz Yaz, iyilikle kötülük, paylaşım ile bencillik arasındaki gerilimi kardeş kavgası aracılığıyla anlatmaktadır. Habil ile Kabil'den beri sürmekte olan mücadeleyi çağdaş bir yorumla aktardığı gerekçesiyle 1964 yılında Berlin Film Festivali’nde de en iyi film seçilmiştir. 
V/25), kutsal kitaplardaki gibi yeryüzünün Tanrı tarafından insanlara ortak bahşedildiği önermesi ile kuramına başlar. Yalnızca mülkiyet teorilerinin değil, mitolojiden kutsal kitaplara kadar pek çok metinde, başlangıçta yeryüzünün bolluğuna değinilir. Mülkiyetin ekseriyetle tarım faaliyetinin keşfi (büyük devrim) sebebiyle yerleşik hale gelen insan topluluklarında sorun oluşturduğu söylenebilir. Diğer yandan insanın hayatta kalması ve soyunu sürdürebilmesi için ortak olanın içinden bir parçasını almak zorundadır. Aksi halde doğanın tüm bolluğuna rağmen kıtlık yaşanır (bolluk paradoksu) ve insan nesli sona ererdi (Locke, 2004: V/ 27-28).

En verimli topraklara sahip olmada, mübadele gibi barışçıl yollar da cebir gibi şiddet yolu da kullanılmış olabilir. Mülkiyet teorisyeni Locke, ortak olandan özel mülkiyeti çıkarmanın zorunluluğunu ortaya çıkarttıktan sonra bu aktarımın adil ve barışçıl şekilde gerçekleştirilmesinin ilkelerini oluşturur. Sosyal teori ile ilgili problem burada başlamaktadır. İnsanın hayatta kalması için ne kadarına ihtiyacı olduğu, sahipliğin ve birikimin diğerlerinin durumunu nasıl etkileyeceği gibi sorunlar ortaya çıkmaktadır. Locke insan topluluklarının ortak yaşam iradelerine zarar vermemek üzere ortak mülkiyetten özele dönüştürülmesi sürecinde insanların izleyeceği kuralları tespit etmeyi dener. Bir kere, kişi ortak olan içinden kendisine ayıracağı şey için emeğini katmak zorundadır (Locke, 2004: V/27). Akan bir dereden ancak avcuna aldığı kadar suya, verimli bir toprağın ise yalnızca ekebildiği kadarına sahip olabilir. Emeğini katmak, tek başına yeterli sayılmaz. Bunun dışında ortak olandan kendi payına olanı alırken, diğer kardeşlerini de düşünerek hareket etmelidir. Diğerlerine yeteri kadar (yeterlilik sınırı) bırakmalı, yiyeceğinden daha fazlasına (çürüme sınırı) sahip olmamalıdır (Locke, 2004: V/31). Üstelik kişi, ortak olana emeğini katarak, insanlığın toplam üretimine katkıda bulunmalı ve bolluğu yaratacak fırsatları yakalamalıdır. Örneğin hiç kullanılmayan araziye meyve ve/veya sebze tohumu ektiğinde, belli bir süre sonra insanlık eskisine oranla daha fazla ürün elde edecektir. Şüphesiz buraya kadar Locke, paranın icat edilmediği, birikimin mümkün olmadığı bir toplumsal düzende mülkiyet ilişkilerinin nasıl düzenlenebileceğine dair kaideleri ortaya koyar. Hükümet Üzerine İki İnceleme adlı eserin bütünü içinde paranın icadı öncesi durum oldukça geniş yer kaplar. Locke para öncesi dönem üzerinde önemle durur ki, paranın kullanıldığı birikim düzenine rehberlik edecek adil düzenin doğrudan kendisi olmasa da ruhu açık şekilde anlaşılır olsun.

Locke, ortak olandan özel mülkiyete doğru dönüşümün iyimser bir teorisini inşa etmektedir. Özel mülkiyeti gerekçelendirirken birkaç temel varsayım sunmaktadır. Bunlardan ilki, insanlığın Tanrı'nın bahşettiği haliyle ortak mülkiyet koşullarında kalması mümkün değildir; özel mülkiyet bir tercih 
değil zorunluluktur. İkinci olarak, zorunluk durumunda özel mülkiyet sistemi sorunlara yol açabilir. Bunun için, izlenmesi gereken ilkelere ihtiyaç vardır. Üçüncü olarak, paranın icadıyla değişen koşullarda ilkeler açık olsa dahi, onları daim kılacak bir aygıta yani sivil yönetime ihtiyaç vardır (Locke, 2004).

Bir toplumda ne tamamen özel ne de bütünüyle ortak mülkiyet söz konusu olabilir. Yönetmen Erksan, kanıksanmış bu gerçekliğin yanında daha çarpıcı bir meseleyi öne çıkarmaktadır. Toprak sabittir ancak su akışkandır, bir parça toprağı elinizde tutarak ona sahip olabilirsiniz oysa su öyle değildir; suyu elde tutmak mümkün değildir (Erksan, 2015). Su, yerin altında kilometrelerce uzunluktaki mesafelerde gezinmektedir. Bu durumda yaşamsal ve iktisadi bir kaynak olarak suyun bölüşümünde hangi ilkeler izlenecektir? Emeğini katma ve bunun yanında diğerlerine de yetecek kadar bırakma şeklindeki Locke'cu ilke sorunu bir noktaya kadar çözmektedir. Zira doğrudan olmasa bile dolaylı olarak yaşamsal bir sıvıdan bahsetmekle birlikte söz konusu vakada ekonomik bir değer olarak suyun sahibi olanın durumu iyileşirken, ondan mahrum olanlarınki kötüye gitmektedir.

Özel mülkiyeti Locke gibi zorunlulukla açılamayan Rousseau için mülkiyet ilişkilerine dayalı medeni toplum temelinde eşitsizlik, adaletsizlik ve yozlaşma vardır. Sahiplik iddiası yalnızca bir bölüşüm sorunu değildir; mülkiyet ilişkileri diğer insanlar (mülksüzler) üzerinde tahakkümü de beraberinde getirir. Rousseau'nun perspektifinden insanlığın başlangıcına ilişkin senaryolar (Hobbes ve Locke'un doğa durumu kurguları) uygar insanın zihninden söküp atamadığı bir takım yanlış izlenimlerin sonucudur (Abramson, 2012: 280-81). Başta mülkiyet olmak üzere insanoğlunun karşılaştığı sorunlar, yine onun 'toplumsallık' gereksiniminden türer. İnsanın diğerleri ile bir araya gelmesi ile birlikte ortaya çıkan tanınma, sivrilme ve öne geçme güdüsünün yarattığı rekabet duygusu, mülkiyetle birlikte tahakküme dönüşür (Rousseau, 1995: 113). Toplumsallaşarak kendilerini diğerleri ile kıyaslayan insanlar, artık mülkiyet elde etme uğruna çatışmaya girer (Rousseau, 1995: 146). Başlangıçta yalnızca doğanın kendisine sunduğu eşitsizlikle mücadele eden insanoğlu, toplumsallık yoluyla politik eşitsizliği de üretir. Dolayısıyla, insanın insanın kurdu olduğuna dair vahşi düşünce, Hobbes'un iddia ettiği gibi ‘doğa durumu' barbarlığında değil, aksine toplumsallık içinde yaşayan medeni insana özgü bir durumdur. Rousseau'cu perspektiften Susuz Yaz'daki köy, medeniyetin eşitsiz, gayri adil ve yoz düzenini gösteren yüzbinlerce örnekten biridir. Etrafı bir çitle çevrilen toprağı, 'bu benimdir' diyerek sahiplenene karşı durmak yerine benzer şekilde davranmanın uygun bulunduğu düzendir (Rousseau, 1995: 135). Rousseau insanoğlunun sahiplik güdüsüne gem vurulmadığ1 için eşitsiz ve gayri adil ilişkilerin kalıcı hale getirdiği fikrindedir. 
Mülkiyeti adalet meselesiyle bir arada ele alan David Hume ise, özel mülkiyeti doğuran koşulları Rousseau'dan farklı bir biçimde açıklamaktadır. Hume göre (1896: 484-5) insanoğlu varlığını sürdürme gücü ve donanımı bakımından diğer canlılara göre yetersiz olduğundan, sorunu toplum içinde yaşamaya yönelerek aşmıştır. Birlikte yaşamak, güçlerini birleştirmeleri suretiyle insanları daha kuvvetli olmaya, karşılıklı yardımlaşmayla kaza ve talihsizliklere daha az maruz kalmaya, işbölümü yaparak yeteneklerini geliştirmeye sevk eder (Hume, 1896: 485). Toplum içinde yaşama zorunluluğu her bir insanın ortak olanın içinden bir parça edinmesine neden olurken, zamanla yinelenen gereksinim açık ya da gizli bir uzlaşının sonucu oluşan kurallarla çerçevelenir. Bu açıklamayla Hume, mülkiyeti temellendirdiği gibi onun kökenini, toplumsal düzen içindeki yerini de açıklar. Yine de mülkiyet ilişkilerinin sorunsuz bir şekilde gerçekleştiğini söylemek mümkün değildir. Hume (1896: 486) insanın bencilliği ve açgözlülüğü gibi basit bir nedene dayandırmak yerine mülk sahipliğinin nedenlerini iki kategori altında ele alır: Doğal içgüdüler ve Dış koşullar.

Hume doğal içgüdülerle (natural temper) insan doğasından kaynaklanan koşulları kast eder. İnsanoğlunun doğasındaki benlik sevgisinden türeyen cömertlik, dar bir çerçevede yani kendisi, ailesi ve sevdikleri arasında geçerlidir (Hume, 1896: 494). Kişinin kendisinden başlayarak çevresinde kadar uzanan çemberde iyilik, sevgi, cömertlik gibi doğal erdemler kendiliğinden oluşur (Yürüşen, 213: 334-35). Söz konusu olan yabancilar olduğunda ise doğal erdemler iş görmemektedir. Diğer bir ifadeyle, insanın doğal içgüdüleri yakın çevresi için başka diğerleri için başka neticeler yaratmaktadır. Öte yandan insanın içgüdülerinden kaynaklanan faktörler kadar dış dünyanın olumsuz koşulları da mülkiyeti yaygın ve kalıcı hale getirmektedir. Hume dış koşullarla (outward circumstances) tabiattaki kıtlıktan kaynaklanan istikrarsızlığı kast eder (1986:495). Bu nedenle yalnızca insanoğluna atfedilen bencillik ya da sınırlı cömertlik değil aynı zamanda kıtlık problemi sahipliğin kökeni ve adalet yoluyla çözülmesi gereken problem yaratır.

Sahipli olan varlıklar bir yana toprağın altında gezinen ve hiç kimseye ait olmayan suyun paylaşımı nasıl olacaktır? Su gibi petrol, doğal gaz, altın ve gümüş gibi toprağın altındaki değerli varlıkların sahipliğinde hangi ilkelerin esas alınacağı meselesi de güncelliğini korumaktadır. Özel mülkiyetin varlığı toprağın üstündekilerde olduğu gibi altındakiler içinde geçerli mi olacaktır, yoksa yerin altında saklı kalmış değerli şeyler hala insanlığın ortak mülkü mü sayılacaktır? Başlangıçta sahipsiz olan ve/veya sahipliği açıkça üstün bir ilkeye dayandırılamayan mal ve değerli varlıkların durumu üzerine düşünülebilir. Örneğin pek çok kişinin para yatırarak oynadığı bir 
şans oyununu varsayalım. Başlangıçta verilen miktara bağlı olarak artmak ve azalmakla birlikte herkesin eşit biçimde ortada biriken paraya sahip olma ihtimali vardır. Lakin şans oyununda büyük ikramiye bir ya da birkaç kişiye çıkar. Sonucun açıklanmasıyla birlikte ikramiyedeki ortaklık ortadan kalkar. Söz konusu olan toprağın altındakiyse, şüphesiz sahibi onun üzerindeki sahipliğin haklarının (şans oyunundaki talihli gibi) kendisinde olduğunu iddia edecektir. Lakin şans oyunundan farklı olarak toprağın altındaki suyun ya da değerli madenin sahipliği konusunda önceden uzlaşı sağlanmış bir görüş birliği yoktur. Mülkiyet üzerinde uzlaşıya varılmamış ilkeler, toplumda anlaşmazlık ve adalet problemine yol açacaktır.

Susuz Yaz'da öne çıkan hususlardan biri de paylaşım sorununun bolluk içinde değil de tedariki güç ve/veya çok daha masraflı yani kıt bir mala dayanmasıdır. Söz konusu olan su gibi kıt bir mal olduğunda, onun tekelci sahibi diğerleri ile paylaşmaya ya da kullanımla ilgili onlarla uzlaşı yapmaya zorlanabilir mi? Mülkiyet hakkı üzerinde duran çağdaş liberallerden Friedrich Hayek'e (2011: 216) göre, rekabetçi piyasalardan ziyade tekelci bir piyasada durumu belirleyecek olan yine durumun kendisidir. Eğer tekel sahibi kişi mübadele yapmayı reddediyor ya da fahiş bir fiyatla imkânsız kılıyorsa, bakılacak husus mal ya da hizmetin niteliği olacaktır. Mesela ünlü bir sanatçıya resmini yaptırmayı çok istediğinde, ressamın istediği fiyat çok yüksek gelse dahi kişi zora maruz birakılmış sayılmaz (Hayek, 2011: 217). Tekelci bir piyasada mübadele teklifinin reddedilmesi ya da koşullarının zorlaştırılması, Hayek'e göre zorlama içermez. Locke'un para öncesi dönemde koyduğu 'istisna' gibi Hayek de koşul koyar. Buna göre, bir tablo gibi sahip olmadan da yaşayabileceğimiz diğer mal ve hizmetler için aynı şey geçerlidir (Hayek, 2011: 217). Ancak Hayek'te tıpkı Susuz Yaz'daki örneğe benzer şekilde tekelcinin bir su kaynağının sahibi olması durumunu ele alır. Su kaynağının kıt olduğu yerde kişinin mübadeleyi reddetmesi (su kaynağını diğerleri ile paylaşmaması) Hayek'e göre açık bir zorlamadır. Yaşamsal olarak muhtaç olunan mal ve hizmetlere sahip kişi(ler), onları paylaşmaya zorlanabilir. Örneğin köydeki tek doktor, salgın bir hastalıkta hizmet vermeyi reddederse, cebir yoluyla hizmet vermeye zorlanabilir. Hayek yaşamsal olan mal ve hizmetler söz konusu olduğunda devletin hukuk normu üretmesini, zor kategorisini genişletme pahasına makul karşılar.

Konu mülkiyet üzerine anlaşmazlık olduğunda, mesele siyaset sahasına taşınmaya, devletin zorlayıcı cebir gücü aracılığıyla hakemlik yapmasına varmaktadır. Susuz Yaz üzerinden yapılan bu sınırlı tartışma ilerleyen kısımda devletin (yargısıyla) dâhil olduğu paylaşıma zorlama ve zorlamama seçeneklerinin eklemlendiği siyasal boyutu ile genişletilecektir. 


\section{Ortak Mülkiyetin Yönetimi Üzerine}

Yılanların Öcü (1962), mülkiyet üçlemesinin ilk filmidir. Fakir Baykurt'un aynı adı taşıyan romanından yola çıkarak senaryosu oluşturulmuştur. Yılanların Öcü’nde, bu kez sorun ortak mülkiyetin idaresinden doğar. Herkese ait olanın korunması ve toplumun tüm üyelerinin yararına uygun şekilde kullanılması problemi ortaya çıkmaktadır. Ülke sınırları içindeki ormanlar, akarsu, göller ve parklar üzerinde o halkın ortak mülkiyeti vardır. Yılanların Öcü’nde de seksen haneli bir köyün ortasındaki meydan, köylülerin tümünün üzerinde hak sahibi olduğu bir ortak mülkiyet konusudur. Köy meydanına ait toprağın bir kısmının muhtar tarafından köy kurulu üyelerinden birine satılması, ortak mülkiyetin yönetimi sorununu doğurur.

1950’lerin kırsalında geçen öykü, başlangıçta köyde yüzyıllar boyunca egemen olan feodal yapının yani ağalık düzenin son bulduğuna dair olumlu gelişme ile başlar. Kırsal, nihayet modern dünyanın ekonomik ve siyasal örgütlenmesinden nasip alacakmış gibi görünür. Köylüler artık başkaları namına değil, kendileri için ekip biçecekleri toprağın sahibi olacakları bir düzene kavuşacaklardır. Zira köyün ağası Necip Bey, elverişli topraklarını ortakçılarına yani köylülere satarak, İstanbul'a göç etmiştir. İç göçün de etkisiyle feodal ilişkilerin çözülmesi, yıllar boyu ağaya kulluk etmiş köylüleri hak sahibi vatandaşa dönüştürme umudu taşımaktadır. Gerçi daha varlıklı olanların yanında yoksul kalmış Kara Bayram ve ailesi gibi haneler, ağır borç altına girerek ancak kıraç topraklara sahip olsalar da yine de kıt kanaat geçinmektedirler. Kulluk edip başkalarının topraklarını değil de kendilerine ait olanı ekip biçtikleri için eskisine nazaran geleceğe dair umutludurlar.

Feodal üretim ilişkilerin çözülmesi ile yerine gelen düzenin iktisadi niteliği öne çıkar. Önceden köylülerin geçimleri tek kişiye, yani ağaya bağlıdır. Yeni düzende ise tek ağa yerine daha fazla toprağa ve hayvana sahip ağaların iktidarı vardır. Varlıklı olan ile yoksul köylüler arasında ekonomik ayrışma devam etmektedir. Farklılıklar olmakla birlikte, özündeki eşitsizliğin devam ettiği yeni düzende beliren en temel farklılık, siyasal erkin yereldeki görünümü olan muhtarlık makamıdır. Ağalık düzeninden kalma boşluğu siyasal olarak muhtarlık ve köy kurulu doldurur.

Feodal ilişkilerin yerini alan siyasal ve hukuksal düzende, en azından yasanın buyurduğu biçimiyle, kişisel çıkarın yerine 'genel yarar'ın hâkim olacağına dair inanç yükselir. Merkezin yönetsel ve yasal erkinden meydana gelen otoritenin muhtar ve köy kurulunca herkese ait olanı koruması ve herkesin 'ortak iyi'yi özeten kararlar alması beklenir. Oysa ortak olanın yönetiminde 
muhtar ve köy kurulu, hakkaniyet ilkesini ve genel yararı ihlal edecek biçimde bir işlem gerçekleştirirler. Vali tarafından salınan vergiyi ödeyebilmek ve siyasi olarak istikbalini kuvvetlendirebilmek için muhtar, ortak mülkiyete dâhil köy meydanının bir kısmını Köy Kurulu üyesi de olan köylülerden birine satar. Köy meydanının bir kısmının satılmasına köylüler ses çıkarmaz. Yalnızca evinin önüne ev yapılarak durumu olumsuz şekilde etkilenen aile itiraz eder, lakin davasında yalnız kalır.

Köydeki yeni durum, mülk sahibi varlıklılar ile devlet (temsilcisi olarak muhtar) sıkı bir işbirliğinin sonucudur. Görünürde ağalık düzenin kalkmasına rağmen kırdaki düzen ve ilişkilerin özündeki adaletsizliğin aynı kalması, Rousseau'nun 'yalancı sözleşmesi'ni hatırlatır. Rousseau (1995: 172) mülk sahipliğinin süregelmesi sonucu eşitsizliğin kalıcı hale gelişinin devlet aracılığıyla gerçekleştiğini ileri sürer. Eşit olmayan koşullarda bir sözleşmenin (devletin) tarafı ya da yurttaşı olmak, bu gayri adil düzeni meşrulaştırır. Zengin ve güçlülerin ittifakıyla kurulan siyasal düzende iktidar sahipleri, ancak mevcut hiyerarşi ve imtiyazların korunmasıyla mevcut düzeni sürdürebilir. Zengin ile fakir, güçlü ile zayıf arasındaki karşıtlık, ilkinden yana olarak sürekli kılınır. Devlet, adaleti tesis eden değil adaletsizliğin temeli olan sömürü ilişkilerini kurumsallaştırandır.

\section{Mülkiyetin Nesnesi Olan İnsan Üzerine}

Erksan'ın gazetenin üçüncü sayfasında okuduğu bir haberden yola çıkarak senaryosunu yazdığı Kuyu, ilk bakışta karşılıksız aşk ilişkisini anlatan binlerce filmden biri gibi görülebilir. Lakin diğer iki filmle birlikte ele alındığında, Kuyu'da insanın insan üzerindeki tahakkümünün mülkiyet ilişkisi içinde gömülü olduğu fark edilecektir. Susuz Yaz ve Yılanların Öcü’nden farklı olarak bu kez sorun insanın insan üzerindeki sahipliğidir. Dünya sinemasında zenci köle-beyaz efendi ya da çocuk köle-yetişkin efendi, maraba köylü-ağa biçimlerinde yansıyan tahakküm ilişkilerini konu alan pek çok başarılı filme rastlamak mümkündür. Lakin Kuyu, kırsalda geçmekle birlikte modern dünya düzeni içinde bir kadının bir erkek tarafından zor yoluyla alıkonmasını, aşk görünümü altında onun hayatı üzerinde tasarrufta bulunulmasını ele alır. Filmin başlangıcında toplumsal ve kültürel olarak kanıksanmış cinsiyet rolleri baskın gibi görünmekle birlikte ilerleyen kısımda kaçırılan kadın karakterinin tek başına esarete karşı (pasif) itaatsizliği, filmi dönemindeki benzerlerinden ayırmaktadır. ${ }^{3}$

3 Kuyu'daki iliş̧kilerin mitolojik bir ögenin modern bir kurgusu olduğunu ileri süren çözümlemeler de yapılmaktadır. Bknz. N. Aysun Akıncı Yüksel, “Metin Erksan'ın Kuyu Filminin Mitolojiye Dayalı Bir Perspektiften Çözümlenmesi”, Anadolu Üniversitesi Sosyal Bilimler Dergisi, Cilt:16, S.4, s. 129-134. 
Hikâyede, genç bir kız köydeki delikanlılardan biri tarafından beğenilmektedir. Kendisinde gönlü olmadığını anlayan adam, kızı kaçırır. Ardından beklenen olmaz, adamın tüm ısrarı ile birlikte tecavüzde bulunması da kızı evliliğe ikna etmeye yetmez. Gerçekte (gazete haberine göre) kız beş kez dağa kaldırılırken, filmde üçe indirilir. Genç kız her seferinde bir şekilde eve dönmeyi başarır, bazen kendi başına döner evine bazen de jandarma gelir kurtarır. Israrından vazgeçmeyen adam, kısa sürelerle ceza evine gönderilir lakin çıkar çıkmaz yine kızı kaçırır. Adamın dağa kaldır(a)madığı zamanlarda kız, oturak âlemleri de denilen meyhanelere de düşer, zengin ve yaşlı bir adamla evlendirilmek de istenir. Düğününden kaçtığında da yine beklenen gerçekleşir ve belalısı tarafından yine dağa kaldırılır.

Kuyu filmi ile Erksan, insanın insan üzerindeki sahipliğinin modern dünyadaki tüm hukuk ve siyasal düzene rağmen süregeldiğini, üstelik bunun toplum tarafından da tuhaf ve yadırgatıcı karşılanmadığını yalın biçimde gösterir. Suyun, toprağın ya da bir sanat eserinin mülkiyet hakkı üzerinde felsefi ve/veya ideolojik bir zeminde tartışma yapılabilir. Eşya üzerindeki mülkiyetin rasyonel gerekçeleri üretilse de, bir kadının mülkiyet konusuna dönüştürülmesini açıklayabilmek mümkün değildir. İnsanın insan üzerindeki sahipliği/mülkiyeti modern dünyanın aklı ve ahlakı tarafından kabul edilebilir değildir. Erksan insanın varlığındaki sahip olma güdüsünün, eşya ya da canlı (hayvan ve insan) üzerinde bir erk ve tahakküm konusu haline geldiğine, kibir, şiddet ve zorbalığa yol açtığına işaret eder. Eşya ve canlı üzerindeki tahakküm, toplumun bir arada yaşamasına yönelik ortak iradesini baltalayan kötülük problemini açığa çıkarmaktadır.

\section{Üç ‘Doğa Durumu’ Aracılığıyla Adaletsizliğin Görünümleri}

Erksan, üç film aracılığıyla mülkiyet ilişkilerinin ürettiği sosyal problemin, toplumun bir arada yaşama iradesini sakatlayacak denli büyük bir çatışma olduğunu gösterir. Susuz Yaz, mülkiyet ve hukuk düzeninin var olduğu sivil toplum halinden insanlığın başlangıcına döner. Henüz paylaşılmamış olanın bölüşümü sorununu sorguya açar. Yılanların Öcü’nde ise herkese ait olanın adil yönetilememesi sorunu vardır. Kuyu'da bu kez insanın mülkiyet konusu olmasından kaynaklı adalet problemi vardır. Üç hikâye de sahipliğin değişik görünümlerini ele alır ve gayri adil bir durumun tasvirini yapar.

Hakkaniyetin çiğnendiği üç hikâyenin de mekânı köy yani kırsaldır. Mülkiyet ilişkilerinin kırsalda baş göstermesi, siyaset felsefesinde de kullanılan doğa durumu senaryolarını andırmaktadır. Doğa durumu-toplum durumu ya da doğal hukuk-pozitif hukuk ikiliği, siyaset felsefesinde insanların niçin bir 
otoriteye başvurarak siyasal birlik oluşturmak istediklerine dair soruları açıklamaya hizmet eder. Doğa durumu, uygarlık öncesi insan ve toplumu, (uygar) toplum durumu ise insanların birlikteliğinden kaynaklanan anlaşmazlıkların çözümü için onay verdikleri siyasal toplumu yani devletli düzeni ifade eder. Kırsalda ortaya çıkan adalet probleminin çözümü için hukuka ve devlete ihtiyaç vardır. Bu bağlamda devletin kökenini, mülkiyet ve adalet problemine dayandıran görüşün üç film aracılığıyla ele alınması yerinde olacaktır.

Çalışmanın ikinci kısmında da yer verilen John Locke'un mülkiyetle ilişkili fikirleri, doğa durumu, adalet ve hukuk mekanizmasıyla birlikte değerlendirildiğinde bu çalışma açısından daha da anlam kazanmaktadır. Locke, özel mülkiyeti meşru bir zemine oturtmakla birlikte, insanlar arasındaki anlaşmazlıkların çözümü için hakemi yani sivil yönetimi işaret etmekteydi. Cebir gücüne sahip olmakla birlikte sivil yönetim, yeryüzünün ortak sahipleri olan insanların temel hürriyetlerini koruyacak, aralarındaki anlaşmazlıkları hakkaniyetli şekilde çözecek yargı ve hukuk düzenidir. Susuz Yaz'da tam da Locke'un sözünü ettiği türden bir anlaşmazlık söz konusudur. Köylüler, suyun sahipliği ve paylaşımı sorununu çözemedikleri için devletin hakemliğine yani adalete ihtiyaç duyarlar. Anlaşmazlık yargıya gider. Yargıdan önce suyun mülkiyetinin, çıktığı toprağın sahibine ait olduğuna, yapılan itirazdan sonra bu kez suyun paylaşımına yönelik bir karar çıkar. Böylece zıt yöndeki iki hükümle devletin, kendisinden beklenen adalet dağıtmada işlevini yerine getiremediği görülür. Bu kritik eşikten sonra ihtilaflı köylüler artık yalnızdırlar, yeni durum bir tür doğa durumuna dönüş demektir. Suyun önüne set çeken köylü ile suyun paylaşılmasında ısrarcı olan köylüler arasında fiili olarak 'savaş durumu' hakim olur. Köylüler, artık kendilerini ve varlıklarını silahla koruyan, kendi adaletlerini sağlamak zorunda kalan barbarlara dönüşürler. Devletin kırsala uğraması ancak işlenen bir cinayetin ardından suçluyu almak içindir.

Yllanlarnn Öcü'nde, Susuz Yaz'daki gibi doğa durumu tablosu görmek mümkün değildir. Hikâyede, devletin temsilcisi yani muhtar vardır. Bu kez adalet problemi, içinde devletin temsilcisinin de olduğu bir grup zengin/güçlü ile yoksul/sahipsiz arasında doğar. Bu kez adaletsizliğin kaynağı, devletin kendisidir. Muhtarın köyün yeni zengini ile iş birliği içinde köy meydanını satması, tam olarak bu düzenin adaletsizliğini tescillemektedir. Oysa ilerleyen kısımda tam da Rousseau'nun ileri sürdüğü ortak iyinin sesi olan 'genel irade' yani yeni ve adil bir sözleşme ile kurulan devlet ya da onun temsilcisi olan kaymakam, bu adaletsizliği düzeltici işlev görmektedir. Böylece yalancı sözleşme ile ezilenlere kabul ettirilen ayrıcalıklı düzen ve sınıflar, yurttaşlık bağıyla ortak iyide buluşturulur. 
Kuyu'da ise bir insanın başka bir insan tarafından defalarca dağa kaldırılması, zorla sahip olunması, başlı başına bir adalet sorunudur. Kızın yaşlı annesi dışında köyde hiç kimsenin bu olaya ses çıkarmaması da sorunun daha derinlere varan izlerini gösterir. Diğer iki öyküden farklı olarak bu kez köy halkı, ahlaki yargıya sahip değilmiş gibi soruna ilgi göstermemekte ya da sanki böyle bir olay yaşanmiyormuş gibi görmezden gelmektedir. Köy halk1, ahlaki yargısı olan insanlardan ziyade cansız nesneler gibidir. Genç bir kızın kaçırılmasına bigânedirler. Defalarca kaçırılmasını da sonrasında zorla yaşlı bir adamla evlendirilmesini de izlerler. Kuyu gerek mekân gerek yarattığı çevre gerekse çizilen hikâye ile Hobbes'un doğa durumu tasvirinden çıkmış gibidir. Hobbes'un doğa durumunda güçlü olan, hayatta kalmak ve arzularını gerçekleştirmek bakımından sonsuz bir özgürlüğe sahiptir. Güçlü, zayıf üzerinde tam tasarrufa sahiptir. Herkesin her şeyi yapmaya hakkının olduğu bu kaotik ortamda güçlünün sözü geçmektedir. Keza Hobbes'un doğa durumunda doğru ile yanlışı, iyi ile kötüyü, adil olanla olmayanı ayıracak bir doğa yasası yoktur (2014: 102-103). Fiili bakımdan olduğu gibi, değerler bak1mından da bir çeşit anarşi hakimdir. Zira doğru ile yanlışı, adil olanla olmayanı ayıran bir ahlaki ölçüt ya da yasa yoktur. Kişinin hayatta kalmak adına yaptıkları, onun doğal hakkı kapsamına alınabilecek kadar geniştir. Keza Kuyu'da meydana gelen yanlış, kötü ve gayri adil olana çevredekilerin duyarsızlığı, bütünüyle Hobbesvari doğa durumuna içkin unsurlar olarak görünmektedir.

Siyaset felsefesinde mülkiyet, adalet ve hukuk ilişkisi sıklıkla ele alınır. Teorilerin büyük bir kısmı mülkiyetten kaynaklanan anlaşmazlıkları doğrudan çözecek bir öneri sunmak yerine, adalet dağıtacak bir hukuk kurumu inşa etmenin gerekliliğinde buluşurlar. Hukuk, toplumu barış içinde bir arada tutacak adaletin cisimleşmiş halidir. Bu sebeple sivil yönetim, ancak toplumda hukukun üstünlüğünü sağlayarak var olabilir. Sivil yönetim ya da devlet, bireyler arasındaki anlaşmazlıklarda hakkaniyet ilkelerini koruyarak hakemlik yapabildiği ölçüde meşruiyet kazanır. Oysa üçlemede, mülkiyet ilişkilerinden türeyen toplumsal sorunları adil şekilde hukuk yoluyla çözen bir sivil yönetimin varlığından söz etmek mümkün değildir. Susuz Yaz'da kırsaldan uzakta bir yarg1 düzeni yani mahkeme olsa dahi, birden fazla ve her iki tarafı da haklı bulan hükümler vermesiyle kendini işlevsiz kılmakta, adalet dağıtamamaktadır. Sivil yönetimin yargısı, adaleti tesis etmekten uzaktır. Yılanların Öcü'nde hakkaniyet devlet eliyle bozulmaktadır. Ortak iyiye hizmet eden, katılımcı ve tarafsız bir devlet eli yoktur. Tıpkı Rousseau'nun sözleşmesindeki gibi güçlünün arkasında duran devlet, onun eli ve/veya ayağı gibi bir uzuv işlevi görmektedir. Adaleti tesis etmek bir yana, bizzat ona zarar vermektedir. Kuyu'da ise, devletin olduğunu bile söylenemez. Etik değerlerin de olmadığı başıboş, düzensiz, 
kaotik bir hal egemendir. Güçlü dilediğini yapabilmekte, kısmen engellense de, nihayetinde önüne ne bir kural, kişi, toplum ya da devlet çlkabilmektedir.

Üç hikâyeye de bakıldığında devlet ya gayri adil düzenin işbirlikçisidir ya hükmü olmayan/işlevsiz kalan yahut hiç olmayandır. Üç hikâyede de mülkiyet kaynaklı anlaşmazlık, husumet ve haksızlıkları tek başlarına karşılamak zorunda kalan mağdurlar vardır. Üç hikâyede de devlet, değişik nedenlerle en temel var oluş amacı olan güvenlik ve adaleti sağlamaktan uzaktır. Erksan'ın çizdiği gerçekçi tabloya göre görünürde, yakın veya uzakta yasaları ve kurumlarıyla cisimleşmiş bir mekanizma olarak devlet olsa da aslında sonuç itibariyle varlıklarını, güvenliklerini ve adaleti sağlayabilecek durumda değildir. Erksan herhangi bir toplumun üyesi olarak insanın karşı karşıya gelebildiği adaletsizlik ve çaresizlik duygusu içinde insana aslında devletli halde dahi doğa durumu koşullarının hâkimiyetini hissettirmektedir. Bu yönüyle üçleme, insanlığın, uzun mücadelelerle geride bıraktığına inandığı korunaksız durumdan hiç de uzaklaşmadığını göstermektedir. Adaleti sağlayacak hukuksal ve siyasal kapasitesinin olmadığı durumda bir başlarına kalan bu insanlar, sorunlarını çözmek için farklı yollara sapmak zorunda kalacaklardır.

\section{Adaletsizliğe Karşı Farklı Direniş Biçimleri}

Üçlemede, devletin adalet dağıtımında başarısızlığı sonucunda doğa durumunun bir başka yönü ortaya çıkar. Haksızlıklarla baş başa kalan insanların mücadelesi ve direnişi başlar. Erksan köylülerin programsız ve kolektif ruhtan yoksun direnişini yetersiz ve anlamsız bir çaba olarak sunar (Scognamillo, 2010: 216). Adaletin yeniden tesisi için zaman zaman pasif zaman zaman da şiddet pratiklerine sarılırlar. Susuz Yaz'da hukuk aracılığıyla devletin çöz(e)mediği sorunla baş bala kalan köylüler, önce bir araya gelerek ne yapabileceklerini tartışırlar. Bu aşamada, adalet arayışı dağınık bir direniş içindedir. Suyu paylaşmayana karşı şiddet kullanarak gözdağı verilmesini isteyenler olduğu gibi, içlerinde sorunu uzlaşıyla çözme taraftarı olanlar da vardır. İki yol da denenir. Husumet içinde oldukları köylüyü ıssız ormanda tek başınayken kıstırıp dövmekten, köpeğini öldürmeye dek şiddet içeren yollara başvurmaktan çekinmezler. Diğer yandan ayağına kadar gidip suyu parayla satın alma gibi bir teklif de sunarlar. Bu bakımdan köy ahalisinin sorunu kendi başlarına çözüme kavuşturma girişimlerinde şiddetin mi, yoksa barış yolunun mu egemen olacağını kestirmek zordur. Sorunlarıyla yalnız kalan köylünün direnişi, kolektif bir ruhtan yoksundur. Köylülerin direnişi, programsız bir dayanışma biçimi olarak yetersiz ve anlamsız bir çabadır. 
Yılanların Öcü’nde ise adaletsizlik, örgütlü bir şekilde, devlet eliyle yapılır. Köyde varlıklı olan birkaç kişi ile siyasal erkin sözcüsü olan muhtar birleşir. Mağdurlar ise genel olarak tüm köylü olmakla birlikte çıkan karardan en çok etkilenen evinin önüne ev yapılacak olan Irazca Ana ve oğludur. Haksızlığa karşı Irazca Ana kararlı bir direniş örneği gösterirken, oğul Kara Bayram daha mülayim, köylüler ise bu durumdan hoşnutsuz olmakla birlikte sessizdirler. Mağdur Irazca Ana ise yapılmaya çalışılan evin temelini doldurmak gibi bozguncu eylemler de yapmakta, yapılan haksızlığı kaymakama duyurmak gibi devletin daha üst erkini görevini yapmaya ve haksızlığı önlemeye de çağırmaktadır. Irazca Ana’nın haksızlığa boyun eğmemesi, tüm baskıya karşı yine de hakkını aramaya devam etmesi, adaletsizliğin çözümü için yegâne seçenek olduğunu göstermektedir (Balc1, 2012:184). Susuz Yaz'da kalabalık ancak kolektif ruhtan yoksun bir iradenin başarısızlığına karşı, Yılanların Öcü’nde tek başına ancak kararlı bir iradenin davasında başarılı olacağı gösterilir (Scognamillo, 2010: 217). Erksan Yılanların Öcü’nde Irazca Ana aracılığılya cesaret duygusunu da ele alır. Erksan, bu karakter aracılığıyla sorunların çözümü için baskıya boyun eğmemeyi, yasaların tanıdığı hakları sonuna kadar aramanın gerekliliğinin üzerinde durur (Erksan'dan aktaran Mücahit Gündoğdu, 2017: 57). Irazca Ana, adaletsizliğin tesisi olan yalancı sözleşmeyi bozarcasına kaymakama başvurarak, bu kez ortak olanın adil yönetimine ulaşmaya başarır. En azından hakkaniyetsiz durum ortadan kaldırılarak, genel iradenin (hak11) sözü geçerli olur. Yönetmen Erksan adaletsizliğin önüne geçilebileceğine izleyiciyi tam inandırmışken, bu kadar şeyden sonra Irazca Ana ve ailesinin o köyde yaşamayacağını gösterir. Aile, göç etmek zorunda kalır.

Kuyu'da haksızlığa uğrayan, diğerlerine göre çok daha azdır, tek kişiden ibarettir. Genç kızın yaşlı annesi dışında hiç kimse olaya müdahil olmaz. Köylü, doğrudan adaletsizliğe ortak değildir ancak ses çıkarmadığı için de kötülüğün katlanarak artmasına hizmet eder. Mağdur genç kız ilk bakışta kendisine yapılanlara karşı güçsüz olsa da zaman içinde yaşadıklarına bağlı olarak bir dönüşüm geçirir (Kayalı, 2015: 23). Erkeğe karşı duramayacak kadar güçsüz olsa da genç kızın pasif bir direniş içinde olduğu fark edilir. Kendisine dayatılan emrivakiye hiçbir şekilde razı olmaz. Bedenini koruyacak kadar güçlü değildir, ancak özgür iradeye sahiptir. Ruhen teslim olmama direncini gösterir. Evlenme teklifine, defalarca kaçırılmasına ve tecavüze rağmen erkeğin iradesine teslim olmaz. Hobbesvari bir doğa durumunda güçsüz olana düşen yalnızca, bir anı kollayarak, esaretine son verebilme cesaretini gösterebilmektir. Kuyu'da mağdur, o an geldiğinde, kendi adaletini verir. Bir sebeple adam kuyuya indiğinde, kuyunun ipini atar, kuyuyu taşla doldurur. Mağdurun verdiği ceza, aşırıdır. İçi hınçla dolu kızın gaddar biçimde adamı cezalandırması, tam anlamıyla doğa 
durumunun aşırılıklarını gösterir. Zira herkesin kendi adaletini sağlamak zorunda kaldığı doğa durumunda vicdanın değil içgüdünün, uygarlığın değil artık barbarlığın sözü geçerlidir

Kuyu filmi ile ilgili yapılan değerlendirmelerde, kız kaçırma gibi Anadolu’ya özgü kültürel motiflere yer verildiğini, ancak yönetmen Erksan'ın 'tutkulu' ve 'coşkun' kişiliğinin sinemaya yansımasıyla farklı bir sona büründüğü yargısı sunulmaktadır (Scognamillo, 2010: 220). Oysa açık şekilde gerçekliğin kendisinde de, beş kez dağa kaldırılan genç kız iradesini teslim almaya çalışanı kuyuya taş atarak öldürmektedir. Oysa Erksan, adaletin olmadığ1 yerde yapılan kötülüğün de, ona karşı verilen bireysel cezanın da ölçüsüz olduğunu göstermektedir. Keza gazete haberine dayanan olayın gerçekliğinde, esir alınan mağdurun verdiği cezada da aynısıdır. Senaryoyu Erksan'ın coşkulu kişiliğinden hareketle aşırılıkla yorumlamak, gerçekliğin dayandığı temeli ve yönetmenin birikimini göz ardı etmektir. Bu bağlamda Kuyu, insanoğlunun kurduğu dünyayı gerçekçi şekilde yorumlayan yönetmenin dehasını ifşa etmektedir.

\section{Sonuç}

Metin Erksan'ın 1960'lı yıllarda çektiği Yılanların Öcü, Susuz Yaz ve Kuyu adlı filmleri, bir yanıyla memleketin koşullarını göstermekte, diğer yanıyla ise herhangi bir zaman ve mekânda gerçekleşmesi mümkün evrensel bir temayı sunmaktadır. Bu çalışmada, yereldeki karşılığından ziyade Erksan'ın işaret ettiği çatışmaların ardında kalan mülkiyet, adalet ve devlet kavramlarına ilişkin teorik bir tartışma yapılmaya çalışılmıştır.

Erksan, bizleri özel mülkiyetin doğasına ilişkin kabulleri de ortak mülkiyetin idaresine ilişkin usulleri de yeni baştan gözden geçirmeye çağırır. Siyasal rejimler ve hukuk sistemi -ortak ve özel- mülkiyet rejimini boşluklara meydan vermeyecek ölçüde düzenlese de yeni bir durum ile kabullerin pek çoğu sakatlanabilmektedir. Toprağın altında dolaşan suyun kime ait olduğu ya da denizlerin ortasında bulunan değerli madenin sahibinin nasıl belirleneceği sorusu, mülkiyet rejimindeki hükümlerin yerleşik kalmasına müsaade etmemektedir. Maddi şeylerin sahipliği kadar günümüzde daha çok öne ç1kan ve yeni bir buluşa ya da gelir getiren kazanca dönüşen fikir ürünlerinin sahipliğine dair belirsizlikler de öne çıkmaktadır. Ortak mülkiyet de zaman zaman en az özel mülkiyet kadar sorunlu bir hal alabilmektedir. Ortak iyinin tespitindeki belirsizlikler gibi uygulamada yapılan usulsüzlükler, toplumun bütününün menfaatine zarar vermektedir. Keza üçlemenin son filmi olan Kuyu'da, tıpkı su ya da toprak gibi insanın da iradesinden bağımsız şekilde 
alıkonması, kapatılması ve satılması, yani mülkiyetin konusu haline gelmesi problemi ele alınır. Yönetmen Erksan bu filmde modern çağda da kaçırılma, bedenden yararlanma, satılma gibi olguların devam ederek, insanın eşya düzeyine indirildiğini göstermektedir. Erksan, düşünce ve duygu dünyamızdaki konfora müdahale eder. Adeta zihinlere kazınmış yargıları kaldırarak, ardındaki rahatsız eden gerçekliği gösterir.

Çalışmanın başlangıcında da belirtildiği gibi yönetmen Erksan'ın zihninde dolaştırdığı yegâne sorun mülkiyet değildir, aynı zamanda adaletsizlik, hukuksuzluk ve direniş eylemidir. Üçlemede, toplumun bir arada yaşama idealini sarsacak denli büyük bir adalet problemi vardır. Üç filmde de, devletin hukuk ve yasası kırsala yani adalet talebinde olanlara ulaşmamaktadır. Erksan'ın öykülerinde ise, beklenilen görevi yerine getiren bir devlet ve hukuk sisteminden bahsetmek mümkün değildir. Erksan'ın üçlemesinden hareketle devlet ya Yılanların Öcü'ndeki gibi güçlü/zengin olanla işbirliği yapan, ya Susuz Yaz'daki gibi haksızlığa hüküm vermekten dahi aciz olan ya da Kuyu'daki gibi zaten olmayandır.

\section{Kaynakça}

Abramson Jeffery (2012), Minerva'nın Baykuşu Batı Siyasi Düşünce Tarihi, çev. İbrahim Yıldız, Ankara: Dipnot Yayınları.

Akçaoğlu, Serap (2003), Necati Cumalı'nın Hikâye ve Romancılı̆ı, Basılmamış Doktora Tezi, Ankara: Ankara Üniversitesi.

Balcı, Sarp (2012), îhlâl Sinemacısı Metin Erksan: Nejat Ulusay ile Söyleşi, Mülkiye Dergisi, s.36:3, ss.179-192.

Baykurt, Fakir (1998), Benli Yazılar, İstanbul: Papirüs Yayınevi.

Dik, Esra (2016), Türkiye'de Erken Cumhuriyet Döneminde (1923-1930) “Köy” Sorunu, SBF Dergisi, s.71:3, ss.693-729.

Erksan, Metin (2015) “Türkiye'de Entelijansiya Yok”, Röp: Hüseyin Sönmez \& Serhat Öztürk, http://www.tsa.org.tr/tr/yazi/yazidetay/133/metin-erksan----turkiye\%E2\%80\%99de-entelijansiya-yok Son Erişim Tarihi, 17.10.2018.

Erksan, Metin (2014), “Metin Erksan ile Türk Sineması Üzerine”, Röp. Sine-Göz, https://www. youtube.com/watch?v=gXRSOwYqKBM, Son Erişim Tarihi, 17.10.2018.

Gündoğdu, Mücahit (2017), Metin Erksan Kuyu'da Bir Yönetmen, Ankara: Cümle Yayınları.

Hayek, Friedrich Von (2013), Özgürlüğün Anayasası, çev. Yusuf Ziya Çelikkaya, Ankara: Bing Bang Yayınları.

Hobbes, Thomas (2014), Leviathan veya Bir Din ve Dünya Devletinin Iç̧eriği, Biçimi ve Kudreti, çev. Semih Lim, İstanbul: YKY.

Hume, David (1896), A Treatise of Human Nature. L.A. Selby-Bigge (Ed.), Oxford: Clarendon Press. 
26 | Belgin Tarhan \& Bora Tarhan

Kayalı, Kurtuluş (2004), Metin Erksan Sinemasını Okumayı Denemek, Ankara: Dost Kitapevi.

Kayalı, Kurtuluş (2015), Metin Erksan, Lütfi Akad ve Yılmaz Güney Türk Sinemasından Öte Türk Kültürünün Deli Dâhisi, Bilgesi ve Gündelik Hayattan Fırlayıp Gelen Efsanesidir, Doğu Batı Dergisi, s.72, ss. 11-25.

Locke, John (2004), Hükümet Üzerine İki İnceleme: Sivil Yönetimin Gerçek Kökeni, Boyutu ve Amacı Üzerine Bir Deneme, çev. Fahri Bakırcı, Ankara: Babil Yayınları.

Rousseau, Jean Jaques (1995), İnsanlar Arasındaki Eşitsizliğin Kaynağı, çev. Nasih Nuri ileri, Ankara: Say Yayıncılık.

Scognamillo, Giovanni (2010), Türk Sinema Tarihi, İstanbul: Kabalcı Yayınevi.

Takım, Abdullah (2012), Demokrat Parti Döneminde Uygulanan Ekonomi Politikaları ve Sonuçları. SBF Dergisi, s. 67:2, ss. 157-187.

Yürüşen, Melih (2013), İnsan Doğası, Sosyal Düzen ve Değişim: David Hume'un Sosyal ve Siyasal Felsefesi, Ankara: Liberte Yayınları. 